\title{
PUBLIC PRIVATE PARTNERSHIPS AND COMMUNITIES: ENCOURAGING ECONOMIC DEVELOPMENT AND CITIZEN PARTICIPATION IN CHARLES COUNTY, MARYLAND
}

Wendy B. Wierzbicki

\begin{abstract}
In a typical community, the commercial/industrial component provides enough tax revenue to offset most infrastructure costs. This is not the case in many suburban areas like Charles County, Maryland whose growth is predominandy residential with little commercial/industrial development. This article examines Public Private Partnerships (PPPs) as an innovative economic development strategy that can address this imbalance. A framework is outlined for the development of a PPP in Charles County that will benefit the councy by increasing the supply of improved, ready-to-occupy commercial/industrial sites, and by acting as a tool to improve communication between citizens and the government.
\end{abstract}

\section{Introduction}

Established more than three hundred years ago, Charles County is located in Maryland's historic southern peninsula. Its economy was once dominated by tobacco farms and fishermen, but during the last two decades Charles County has been transformed into an affordable suburban bedroom community, located 23 miles to the north of Washington D.C. An estimated 60 percent of the county's residents now commute to jobs located in the Washington Metropolitan region. ${ }^{1}$ At the same time, commercial/industrial economic development has been limited because many businesses do not view Charles County as a viable location in which to develop. The county's Economic Development Commission (EDC) has cited high property costs in comparison to surrounding counties, lack of improved industrial/commercial sites, and lack of direct access to major interstate highways for transportation of goods as reasons for the county's slow developmenr. ${ }^{2}$. Yet its unemployment rate, approximately 4 percent, is low when compared to surrounding localities, and residents are highly skilled, although most of the jobs available in the county are low paying, service-oriented jobs. ${ }^{3}$

Wendy B. Wierzbicki holds a Master of Public Administration degree with a concentration in Urban Planning from The George Washington University, and a Bachelor of Arts degree in Government and Politics from George Mason University. She currently works for the U.S. General Accounting Office in the Resources, Community, and Economic Development Division, and has been a resident of Charles County, Maryland for three years.
The lack of economic development has impeded the county's efforts to provide well-paying jobs and necessary services to residents because of the resulting imbalance between tax revenue versus outlays. Residential development and the services associated with it usually cost more than the taxes generated by residents. In a typical community, the commercial/industrial component provides enough tax revenue to offset most required services and infrastructure costs, and does not require the level of services that an increase in residential growth demands. However, this is not the case in many suburban areas like Charles County, where growth is predominantly residential and is not accompanied by commercial/industrial development.

Public Private Partnerships (PPPs) are an example of a strategy that utilizes the private sector to assist the public sector in stimulating and managing various types of economic development. Examples of PPPs range from downtown revitalization efforts to charter schools. This article will examine PPPs as one example of an innovative economic development strategy that can address concerns of struggling suburban regions like Charles County, and will demonstrate how PPPs can act as catalysts for the type of commercial/ industrial economic development that would help remedy Charles County's economic imbalance.

In general, PPPs can help to establish a common agenda between private investors who own the land, communities that use the land, and public officials who regulate its use. For Charles County, PPPs can help increase the num- 
ber of improved, ready-to-occupy commercial/industrial sites in the locality. Based on examples, such as the Baltimore Inner Harbor PPP and a review of economic development literature, a framework will be outlined that addresses the major factors needed in the creation and management of a PPP and the specifics as they apply to Charles County, focusing on fifty acres in the area of the county known as the Bryan's Road Corridor.

\section{Public Private Partnerships}

\section{What Are PPPs?}

The term public private partnership (PPP) is a loose one and describes a range of collaborative efforts between the public and private sectors. Multiple definitions exist. One widely cited definition describes PPPs as "a range of joint ventures, where government and one or more firms share the risks and equity interests on relatively equal footing." ${ }^{4}$ According to Walzer and Jacobs, "PPPs are formal relationships in which both the city and the private agency have a substantial, long-term, financial interest, for which each business provides stated benefits." PPPs are usually formalized through some type of an agreement between the public and privare entity, which outlines each partner's roles and responsibilities.

PPPs are unlike the typical incentives and subsidies that most local governments supply to incoming businesses, such as tax exemptions or free use of publicly owned land. While these tactics may often attract new business, they often minimize future tax receipts for the municipality. In a review of economic development strategies, Shaffer states that "evidence demonstrates that incentives have a marginal impact on location and investment decisions." Tax concessions made by city governments to attract or retain major employers or the use of government funds used to finance the construction of sports facilities are examples of typical incentives used by localities. Critics argue that the benefits associated with these significant public costs are uncertain at best; "employers and teams are not required to guarantee any particular number of new jobs, period of operation, or level of eventual tax revenues if the project survives." PPPs are different than these incentives in that the benefits and risks are assumed by both the public and private sectors. Under a PPP, the public entity is still taking a risk partnering with the private sector, but these risks are shared, and, therefore, lessened.

\section{History of PPPs}

PPPs are not a new development concept. Indeed, the concept's roots can be found in many of the nation's largest social programs. As part of his New Deal, Franklin Roosevelt called for business groups and government to work together with planners to find common ground and make decisions based on scientific information and compromise. $^{8}$ Beginning in the 1960 s, entrepreneurial fiscal approaches, such as PPPs, were introduced to localities through participation in federal economic development programs. Federal programs charged with providing experience to localities using market-based strategies include the Economic Development Administration's Title II Business Development Loans, Title IX Special Economic Development and Adjustment Assistance, the Community Development Block Grant (CDBG) program, and the Urban Development Action Grant (UDAG) program." While not designed to create entrepreneurs out of local officials, by the mid 1970 s, these programs had laid the groundwork for localities to assume market-based roles by encouraging a wide range of local economic development activities.

The Title II and Title IX programs required localities to use federal funds to make loans that encouraged the formation of quasi-public organizations and local development corporations with greater community involvement than in the past. The CDBG amendments in 1984 allowed cities to direct funds to private entities where "necessary and appropriate" and especially if sponsored by local development corporations, neighborhood based nonprofit organizations, or small business investment companies. Under the UDAG program, the most market-based approach, local officials were required to form relationships with businesses and other agencies before funds would be allocated for development and in many instances used funds as public investment capital. $^{10}$

Partnerships and other market-based strategies became more commonplace in the 1980s as a matter of necessity because of the overall reduction in grants and other federal funds. As a result, many local officials looked to other sources of support for economic development activities, and both public and private entities increasingly found themselves looking to collaboration as a way to collect these needed funds. In 1989, nearly two-thirds of one hundred cities surveyed about economic development strategies reported that the use of PPPs for economic development was very active to extremely active in their cities. ${ }^{11}$ For 75 percent of cities surveyed, this was a substantial increase in activity when compared to responses in $1984 . .^{12}$ 
In the past decade, PPPs have expanded to include a broader range of project types and collaborative efforts between the public and private sectors. Traditionally, partnerships between public and private entities have concentrated on financial aspects with little coordination of efforts or participation. PPP use focused on providing financial resources, such as when a public entiry provides the capital or donates parcels of land for redevelopment of urban areas. While these relationships are still common, the roles of the public and private sector have expanded to include, in some cases, joint management of development efforts. Structures have emerged that include arrangements in which the public and private entity coordinate and share in the financial burdens and management functions. In a 1996 survey of urban planning professionals, 89 percent of respondents claimed that PPPs were used more in the 1990 s than in the past. ${ }^{13}$ These same professionals also indicated that use will only increase in the near future because of the many success stories associated with the use of PPPs. Such data demonstrates the ongoing interest associated with PPPs and the growing role that they have played in the $1990 \mathrm{~s}^{14}$

\section{Strengths of PPPs}

There are many reasons municipalities pursue PPPs. Perhaps most importantly, PPPs generate resources for projects that are not always feasible in a typical government environment of limited resources. They also normally have fewer restrictions on contracting, procurement, and personnel administration than do governmental or quasi-governmental enterprises. ${ }^{15}$ In addirion, PPPs do not usually rely on assessing property owners or require approving legislation to operare, unlike other economic development strategies. This makes them attractive to both government and its citizens.

The benefits provided by a successful PPP are twofold. Unlike the incentives/concessions model mentioned above, both the public and private entity not only benefit from the rewards but also share the risks. In this connection, another reason municipalities consider PPPs a positive porential economic development strategy is that "the organizational structure and funding of a PPP facilitates heightened stakeholder ownership by giving greater control and financial direction of activities to directly affected property owners and businesses." ${ }^{16}$ Thus, the nature of PPPs ensures that those who are directly involved-privare developers, local banks, community organizations, and local governments-receive the benefits but also pay the costs of projects. By including the private sector as a partner, governments and communities are able to do more to improve the quality of the development effort by utilizing the many skills and resources that the private sector possesses, such as flexibility, manpower, access to resources, and technical expertise. For their part, communities and local governments are able to better guide and influence the shape of the development. In a PPP, both the private and public sector participants have an interest in development as a revenue raiser and a job crearor, and this common agenda allows for complementary allocation of resources and cooperation among the parties involved.

\section{Potential Weaknesses of PPPS}

Some critics of PPPs, however, view these arrangements as an attempt by local governments to compensate for cuts in spending. In some cases this is correct; PPPs are an attempe to encourage economic development despite reductions in government ourlays. PPPs reduce the burden on local governments and industry by creating a method through which planning and/or funding of developments can be accomplished in a way that allows both entities to meet varying goals and objectives and save tax dollars. Critics also claim that PPPs lure attention away from the compelling need for government institutions to operate as they should. ${ }^{17}$ By lessening government responsibility, they claim that governments opt out of some of their basic duties, passing them on to private entities. Critics have also gone so far as to claim that PPPs act as a third form of government, which may undermine representative democracy by including only those involved with the partnership, creating an atmosphere where special interests influence government decisions. ${ }^{1 \mathrm{H}}$ This argument runs counter to the view that PPPs increase inclusiveness by involving more stakeholders in the development process. These criticisms are valid; partnerships can generate the problems outlined above, but results depend on how a specific partnership is structured. Local governments and other partners can avoid these pirfalls by including specific provisions to address these issues in partnering agreements.

\section{Case Study-Baltimore's Inner Harbor' Charles Center}

Baltimore's Inner Harbor/Charles Center project is a particularly well-known tribute to the success of PPPs. Examining its development demonstrates important lessons for localities like Charles Councy that are interested in the use of the PPP strategy.

Since 1956 redevelopment efforts have been underway at Baltimore's once rundown commercial waterfront, transforming it into the current focal point for the city's commercial and residential revitalization. The private partners, including the Retail Merchants Association and the Commitce for Downtown Revitalization, provided the plans, the developer, and 70 percent of the initial capital costs. 
The City of Baltimore provided the necessary infrastructure investments, additional revenue, and assisted in the movement of the project through the city and state bureaucracy. $^{19}$

The closing of one of the city's biggest department stores triggered downtown Baltimore's redevelopment efforts. Over several years, the city experienced declining retail sales, movement of six major employers out of the downtown area, falling property assessments and increasing vacancy rates. ${ }^{20}$ The Retail Merchants Association formed the Committee for Downtown and recruited members from uriliries, banks, and property owners to look into what other cities were doing to cope with similar issues. Around the same time, another business/civic group, the Greater Baltimore Commitree, composed of 100 top executives in the metro region, was formed and created a wholly owned subsidiary called the Planning Council to address redevelopment issues. The two private organizations identified downtown renewal as a top priority. The comprehensive study and plan for action were funded by both the Committee for Downtown and the Greater Baltimore Committee.

The plans were then turned over to the Baltimore Urban Renewal and Housing agency for review and feasibility study. After initial review, the city council adopted the plan as the official urban renewal plan, marking the official beginning of the historic partnership between the city government and the business community toward the common goal of city revitalization. This relationship was formalized with the creation of the Charles Center Managemenr Office, which implemented the project plan under a contract with the city. ${ }^{21}$ This office combined the flexibility of a private corporation with the city government's power to raise capital and acquire land through its power of eminent domain.

The second part of the redevelopment effort, reclaiming the inner harbor, began when the Planning Council was again commissioned to prepare a proposal. Funding was raised by three groups: the city, the Greater Baltimore Committee, and the Commitree for Downtown. This three-member partnership increased the government's role and initiative in the redevelopment process. In 1964, the voters authorized $\$ 2$ million in bonds to finance the first phase of the thirty year, $\$ 260$ million plan. ${ }^{22}$ The city was fortunate to own eighteen acres along the waterfront, which they provided for the development. Part of this plan also included the opening of the harbor's edge to the public, which the planners saw as the critical piece to the future success of the project.
The inner harbor portion of the redevelopment, a three phase effort, was so large that it required the creation of a specialized management entity to implement the program. The Charles Center Management Office was changed into Charles Center-Inner Harbor Management Inc., a nonprofit corporation with the architect involved from the beginning as the chairman. Other members included previous leaders in the U.S. Urban Renewal Administration and a past director of the Baltimore Urban Renewal and Housing Commission., ${ }^{23}$ Throughout the phased effort, voters approved large loans for the projecr, and the City Council and the Mayor approved plans. In addition, Baltimore took full advantage of federal grants that had begun under the Charles Center project, including $\$ 22.4$ million for phase one of the project. ${ }^{24}$ These funds along with the voter-approved bond financing kepe the project running.

By 1976 , twenty years after plans began, there was physical evidence that the harbor and downtown had curned the corner. Meanwhile, other partnering arrangements continued in the Inner Harbor area. In 1978, the Rouse Company proposed the building of Harbor Place, the shopping component of the redevelopment effort. Citizen groups expressed concerns, however, that the newly placed public spaces would be taken over by commercial shops. Proving itself responsive to citizen criticisms, the Rouse Company moved to include citizen groups and their suggestions into the redevelopment process, incorporating ideas such as a plan for minority hiring, use of minority owned businesses, high tax returns for the city, and careful atrention to design. Therefore, with the backing of the city, business community, and many citizen groups, a referendum on Harbor Place passed with 54 percent of the vote. ${ }^{25}$

The Inner Harbor redevelopment is a positive example of the benefits of using a PPP to encourage economic development. The effort has been a clear success, with sales more than twice that of traditional shopping malls, over 2,000 new jobs, and millions of dollars paid in city and state taxes and parking revenues. ${ }^{26}$ It has also spurred additional development in the Inner Harbor area, such as Camden Yards Stadium and the Baltimore Aquarium. Today many foreign and domestic governments visit Baltimore to take back the partnering lessons of the Inner Harbor's success. 


\section{Background of Charles County}

\section{Economic Conditions}

Charles County is one of the three counties that make up the region called southern Maryland and has a population of approximately $118,000 .{ }^{27}$ Through its history, Charles County has been characterized by "a number of compact rural settlements spread amongst farmland, waterway, shoreline, and undisturbed natural areas." ${ }^{28}$ Unique among Maryland counties, 80 percent of Charles County's land use is in agriculture and forest. Indeed, the county's history and rural character are important to long-time and many new residents who want Charles County to maintain its identity. The desire of the county to preserve its rural character has led it to outline specific development areas, thereby limiting the amount of land available for development. Seventeen percent of Charles County's tax base consists of commercial/industrial property, and 72 percent of residential property. ${ }^{29}$ Since 1980, Charles County has seen an increase of 4 percent in the amount of commercial/industrial development and low job growth. ${ }^{30}$ This has not kept pace with the 80 percent increase in residential growth, and the resulting increase in the demand for county services. ${ }^{31}$

The projected employment growth of ten thousand jobs by 2005 is less than one-half of the projected population

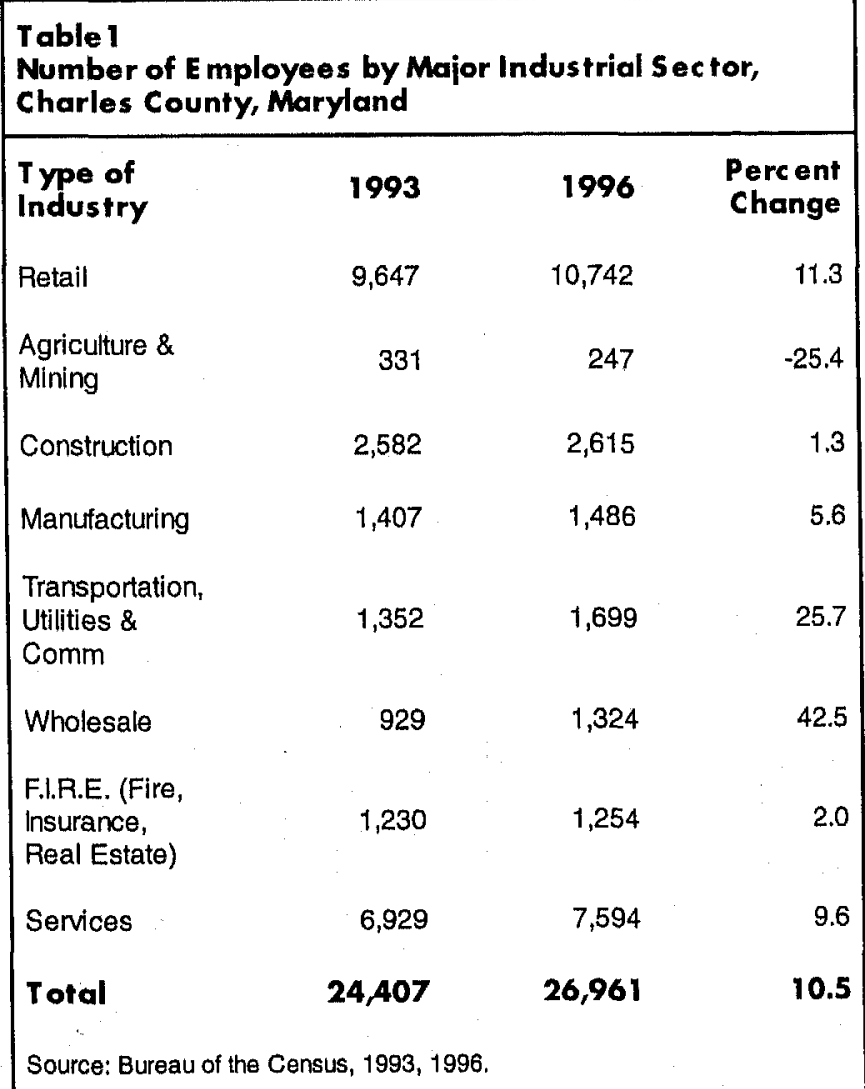

growth. $^{32}$ The sectors of the economy that grew fastest between 1993 and 1996 were wholesale, transportation, retail, and the services sector. ${ }^{33}$ Table 1 gives an overview of the number of Charles County employees by major industrial sector. These numbers show the increase in the four sectors and highlight those areas that have declined.

The Charles County EDC, a nonprofit, publicly funded entity, has attempted to balance the residential, retail, and commercial developments with increased office and industrial development, but has been unable to attract any large businesses to the county. Like many other counties in the nation, Charles County's EDC has outlined target industries for preferred development; information technology, engineering and management services, and heal th and retirement services lead that list. In addition, the EDC has promoted the growth of light manufacturing, warehouses, and distribution businesses. The EDC has been working to attract these types of businesses to develop a strong, diversified, and resilient local economic base that can provide quality jobs to local workers and balance the tax structure. Unfortunately, this work has yet to produce many tangible results.

This slow economic development has been substantially outpaced by residential growth. Over the last two decades, the outward movement of Washington residents to the suburbs has transformed the northern section of Charles County into a suburban developmental area that has attracted increasing residential development. In fact, Charles County was the third fastest growing county in the state between 1980 and $1990 .^{34}$ The county has seen a 62 percent increase in population $(72,751$ to 118,000$)$ from $1982-1998$, with an expected population increase of another 52 percent $(118,000$ to 182,552$)$ by $2020 .{ }^{35}$ As noted above, job growth has not kept pace with this population growth. Those jobs that have been created in the county have been mostly in retail and the service sectors and average a 3 percent per year with an 8 percent total increase between 1993 and $1998 .^{36}$

While Charles County covers a large area with multiple population centers, including Waldorf, Indian Head, La Plata, and White Plains, there are only two incorporated townships: La Plata, the county seat, and Indian Head. Waldorf is not incorporated but has the largest population in the county and acts as the main development district. The Waldorf and Pomonkey voting districts of the county, including the Bryan's Road Corridor, expect the most population and residential unit development in the near fu- 
ture; 73 percent of the growth in residential units is expected to occur in these two districts. ${ }^{37}$ The rapid development in specific areas of the county has caused many planning difficulties, including sprawl development, increased volume throughout the county's main traffic corridors, housing shortage problems, disappearing farms, and difficulty in providing services.

Positive economic development provides increased local employment, rising family income, and a balanced tax base. Unmanaged growth, especially of the bedroom community type, which currently exists in Charles County, results in greater and more costly demand for public services without a comparable increase in the tax base, leaving a locality unable to meet those demands. Sixty percent, or twenty-six thousand residents, commute out of Charles County to work. This trend will likely continue based on current population projections and the lack of well-paying commercial/industrial jobs to match the skill level of residents. Economic development in the county must therefore encourage industrial/commercial development, which will increase the number of jobs and possibly reduce the percentage of residents commuting to jobs outside of the county. A balance should be struck between residential and commercial/industrial economic development for Charles County to maintain its goal of "preserving the present character of the county and enhancing the quality of life for its citizens while still maintaining a pace of growth and development. ${ }^{{ }^{38}}$ A PPP can be a valuable tool in helping the county to achieve that goal.

\section{County Tax Base}

It is important to review Charles County's property tax structure, which is typical of many suburban counties

\begin{tabular}{|c|c|}
\hline \multicolumn{2}{|c|}{$\begin{array}{l}\text { Type of Property by Category as a Percentage of Total } \\
\text { Assessed Property, Charles County, Maryland }\end{array}$} \\
\hline Type of Property & Percentage of Total \\
\hline Residential & 72 \\
\hline Industrial & 4 \\
\hline Commercial & 13 \\
\hline Agricultural & 3 \\
\hline Exempt & 8 \\
\hline Source: Lipman, Frizati, & \\
\hline
\end{tabular}

that have an imbalance between residential and commercial/industrial economic development. The preferred balance berween residential and commercial/industrial property taxes is approximately 65-70 percent residential and 20-25 percent commetcial/industrial. ${ }^{39}$ Table 2 indicates that Charles County is well below this percentage with commercial and industrial property taxes equaling only 17 percent of total property taxes.

The ability of Charles County to address its tax base problem depends on a number of factors. One of the most important is the availability of buildings and lots zoned for commercial and industrial uses and served by public utilities. Sites play an often critical role in a firm's decision to locate given the one-time settlement costs to a company. ${ }^{40}$ It benefits a company if a locality has infrastructure and office space already in place, thus eliminating the need for the exrra outlay of dollars for building and infrastructure expenses and reducing the time before full operation.

Improved sites in Charles County are limited because of the county's policy of requiring developers to cover all costs associated with development. This policy was implemented to curb residential development problems, but it has in fact hurt the county's competitive position since unimproved land does not typically do well against the ample ready-to-build commercial/industrial sites in other nearby jurisdictions. ${ }^{41}$ Land is available for developers, but the county does not have adequate funds to improve sites and is furthermore not prepared to raise property taxes for this purpose. Thus, developers have to pay for basic infrastructure costs out of pocket.

Making developers cover these costs is realistic in an area that is attractive to business, but not in Charles County, which has struggled for years to attract commercial/industrial interests to settle in the county. PPPs can help to remedy this lack of ready-to-build sites by encouraging localities and private developers to share in the costs of sire improvement and to extend basic infrastructure to sites throughout the county.

\section{Prior Economic Development Initiative: Chapman's Forest}

It would be difficult to fully understand the economic development choices available in Charles County without describing the background leading up to the EDC's decision to choose the Bryan's Road Corridor site as a possible good fit for the PPP described in this article. The historical 
discussion in the section below will not only outline a previous economic development initiative in Charles County, but will also identify the stakeholders that play a crucial role in influencing economic development decisions. This situation has caused continuing difficulties, creating an "us versus them" rift that is not conducive to community development. The lessons learned from the attempt at economic development in the Chapman's Forest area can help avoid past mistakes and be applied to the current analysis of the possibilities for PPPs in other county areas like Bryan's Road.

\section{Chapman's Forest Development}

Chapman's Forest is a section of Charles County which includes a historic site, Mt. Aventine, and approximately Seventy-frve homes. Mr. Aventine is a colonial era site given as a land grant by Lord Baltimore to the previous owners. In 1986, twenty-five hundred acres of land at this site, part of which lies along the Potomac River, was purchased by Legend Properties, Inc. Their development plan, "Chapman's Landing," included forty-five hundred dwelling units, two and one-quarter miles of commercial sites, two elementary schools, two and one-quarter miles of waterfront access and extensive recreational amenities. ${ }^{42}$ The county was not required to provide anything to assist in the development of Chapman's Landing as the costs of development were to be incurred by the developer. The development was expected to be completed in 2005. Preliminary construction began and $\$ 300-400,000$ was invested. ${ }^{43}$ A federal wetlands permit, which would allow the next level of construction to continue on the site, was approved in June 1997 and was then sent to the state permit office where it sat waiting for approval.

Historic preservation and environmental interests were opposed to the Chapman's Landing development. Citing various environmental issues, the historic house, and the acting horse farm as items of concern, Friends of Mt. Aventine, a small group of local activists, rallied against the development, viewing it as a basic threat to the rural character of this section of the county. In 1996, Friends of Mt. Aventine, with the help of the Sierra Club, began to collect support for preservation of the site. The Sierra Club issued an alert, referring to the development as a potential "edge city" that would degrade the area's fish and wildlife habitat. ${ }^{44}$ An "edge city" is a suburban area which over time becomes a city in itself, no longer just an outgrowth of a larger metropolitan area with one center city. This alert urged citizens to contact Governor Glendening to encourage him to require an extensive Environmental Impact Study, in addition to the federal and state requirements that had already been com- pleted.

As a result of the outcry and lobbying by environmental groups and other citizens, Governor Glendening, who had just run a successful gubernatorial campaign that emphasized a commitment to environmental issues and smart growth, purchased the land from Legend Properties. County commissioners voiced their outrage to the state, but to no avail. Initially, the state was only going to buy the parcel of land that was along the waterfront, but changed its mind and decided that preservation of the entire twenty-five hundred acre parcel was necessary. The purchase occurred on October $28,1998 .{ }^{45}$ With the sale of Chapman's Landing to the state, the outlook for economic development in Charles County changed.

The Chapman's conflict embodies the problems that Charles County has and will continue to have if economic development policies and other planning processes do not change. The County should seek involvement and support from residents early on in the future to avoid similar problems. The rural character of the county can be maintained, and growth can occur, if citizens become involved in the planning process. The inability for development on the Chapman's site has changed the situation for the better. This experience has changed the county's outlook and approach by encouraging the use of new strategies, such as PPPs, to affect development. It is a benefit to the county to learn from the mistakes of Chapman's Landing. The opportunity for development in the Bryan's Road Corridor using a PPP may be a positive way to ceremonially regain control over economic development after the devastating blow dealt by the state's purchase of the Chapman's Landing area. The Bryan's Road development dealings should be as open as possible and include the opinions of as many of the people that mighr be affected by development as possible. A PPP would be an excellent mechanism through which to encourage wider involvement:

\section{Bryan's Road Corridor: An Opportunity for a PPP in Charles County}

The area that has been targeted for development by the county EDC is approximately fifty acres in the proposed development district along Bryan's Road. This acreage was originally part of the twenty-five hundred acres of the Chapman's Landing site purchased by the state in 1998, but is expected to be returned to the county for development as a result of a petition by county commissioners to Governor Glendening. This petition is still pending as of March 2000.46 
The Bryan's Road Corridor is located in western Charles County in the Pomonkey election district. While this area has experienced increased development in the last decade, there are no large businesses and a small, privately owned airport takes up the most land in the surrounding area. In addition, there are various sites surrounding the airport that are zoned for industrial/commercial use, but only average twenty acres in size. While

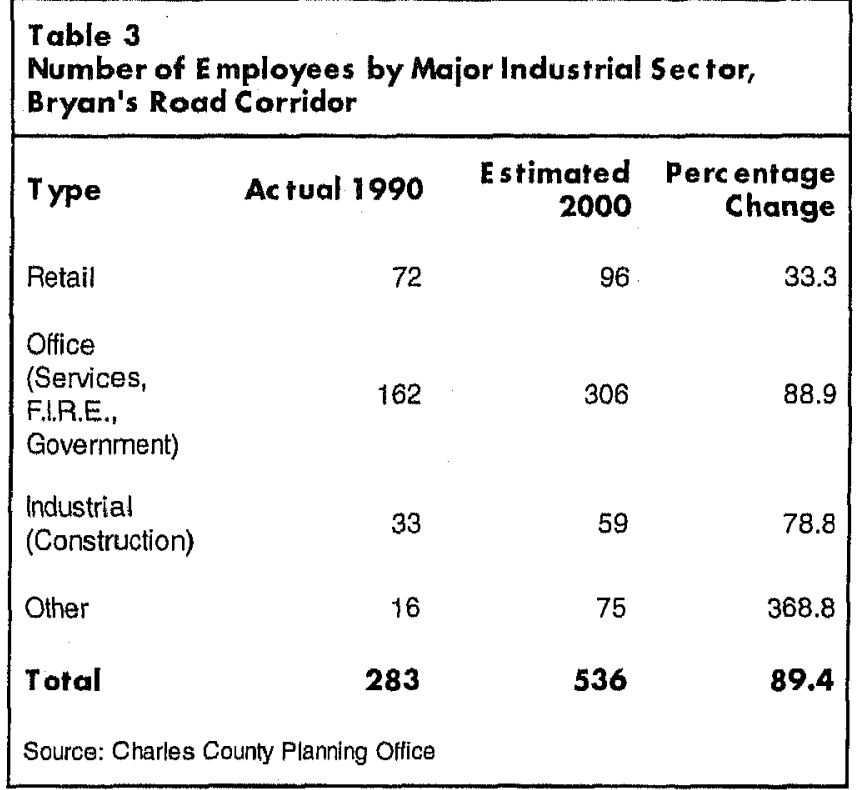

these lots are available, they are not sufficient size for many types of development. ${ }^{47}$ Table 3 gives an overview of the types of development that are in the Bryan's Road Corridor. This table lists the number of jobs in the traffic analysis zones based on major industrial sector. The types of sectors given vary between 1990 and 2000 because of the differences between actual data and estimates. The 1990 actual data has been compressed into four types for comparison purposes since the 2000 data is estimated using these broader types. Though this causes some evaluation problems, trends are still discernable.

The Bryan's Road area has experienced an approximated increase in population of 10 percent from 11,026 in 1980 to 12,131 in $1995,{ }^{48}$ which is commensurate with the county as a whole. Based on the traffic analysis zone data for 1990 and estimates for 2000, the Bryan's Road Corridor is estimating a 49 percent increase in jobs by the year 2000 , 49 substantially higher than the overall county trend. The dominance of retail, services, and construction continues. This development assumes improvements in infrastructure, such as water and sewer, which will not occur under current county plans because of funding problems without the creation of a PPP.

The EDC identified this area as a prime development opportunity because of the airport and the advantages access to an airport provides to a business. It is estimated that it will take an investment between $\$ 1-1.5$ million to bring water and sewer services to this property. ${ }^{50}$ The county, however, does not have this level of funding to invest. This shortfall encouraged the EDC to seek out and identify a different strategy to fund the infrastructure costs associated with the development of this site. Analysis of the strengths of PPPs and the particular challenges faced by Charles County suggests that PPPs are a viable option for the targeted Bryan's Road area as well as the county as a whole.

The following section will analyze how Charles County and its business community can further use PPPs to achieve their goals and objectives. In addition, it will suggest how Charles County can use PPPs to better communicate with citizens and reduce the potential for unsuccessful projects, such as Chapman's Landing, using the Baltimore Inner Harbor Project as an example of a successful application of a PPP.

\section{Creating a PPP in the Bryan's Road Corridor}

To address the concerns described above, the county should begin the partnering process by establishing a relationship with relevant private stakeholders, which include the airport owner and private landowners. In order to ensure that the partnership arrangement meets the priorities of all those involved, it is necessary to formalize the relationship by developing a Memorandum of Agreement (MOA) or Memorandum of Understanding (MOU) that specifically outlines the benefits and responsibilities of each participant. When crafting the MOA or MOU, participants should agree on goals and objectives before making decisions. To this end, involving the expertise of lawyers is essential to building a good MOA or MOU, ${ }^{28}$ In addition, the PPP should act as a team to build consensus within the Bryan's Road community to limit the not-in-my-back-yard (NIMBY) mentality.

Political issues such as those experienced in the Chapman's Landing development and the Baltimore Inner Harbor/ Charles Center project can stifle or encourage development in a locality. PPPs address these political issues through early involvement of community stakeholders in the decisionmaking and planning process. Including the various players in a community can help to avoid failures like Chapman's Landing and can foster the successes outlined in the Baltimore Inner Harbor example. In this way, PPPs avoid failures by encouraging thoughtful review of local 
planning goals and objectives and insist on the setring of economic development priorities.

The use of PPP strategies can increase the quality of communication for those in a locality by involving groups with special interests that may have had adversarial relationships in the past. This involvement can encourage communication between the groups by fostering an understanding of each stakeholder's challenges and responsibilities. This makes it more likely that decisions will be made focusing on what is best for the community versus what is best for a particular interest group, such as a local environmental group or the Chamber of Commerce. Improved decisionmaking can strike a better balance between the benefits and risks associated with a specific development. Overall, the use of PPP strategies can help Bryan's Road, or any community, recognize its strengths and encourage positive economic development for the entire community.

\section{Future Uses of the PPP Strategy}

To facilitate the use of PPPs throughout the county, a new entity should be created whose mission is to encourage partnerships. This entity should include active participation, leadership, and contributions from the corporate community as well as the residential community. ${ }^{51}$ The Chamber of Commerce, EDC, citizens groups, environmental groups, and others should be included in this body and should work together to determine how best to invest in the community. This entity could be a countywide, nonprofic $501 \mathrm{c}(3)$ organization, such as Charles Center/Inner Harbor Management, Inc. created by the Baltimore's Inner Harbor project, where businesses can count contributions as business expenses for tax deduction. The EDC already holds a $501 \mathrm{c}(3)$ status, but a single organization focused on facilitating PPP efforts may be more successful in establishing PPPs because of concentrated markering techniques and resources.

To garner political support, it would be helpful for the county to identify good examples of partnerships to educate officials and the public about their potential; the Baltimore Inner Harbor Project is a fine example of a PPP success. ${ }^{52}$ Marketing is a key element to the success and increased use of PPPs and positive examples will help to focus the county's attention on the benefits associated with the PPP concept. In addition, the public entity in a PPP must balance accountability and protections for public investments with flexibility to permit experimentation in the roles and responsibilities of partnership participants in order to move beyond the monetary-focused PPPs of the past. ${ }^{3 .}$ If PPI's are to be successful, public and privare participants must act as unanimous and reliable partners who will stand behind the PPP's decisions as well as its members. ${ }^{54}$

\section{Elements of Successful PPPs}

Defining the "success" of a PPP is difficult. The ambiguous nature of partnerships and the varied ways in which they are defined and managed make data collection and analysis difficult. Success depends on many factors that cannot be measured until a project has been completed. Walzer and Jacobs have attempted to define elements common to successful partnerships. In successful PPPs, parricipants develop criteria that encourage a mutual understanding of the parrnership's purpose and expectarions. ${ }^{35}$ Constituents have compatible goals and objectives based on discussion and involvement of the community so that the public views results positively. Some other factors include a clearly identified need for the project and comprehensive community planning. In addition, participants in successful partnerships demonstrate flexibiliry and sensitivity to the market and political issues and demonstrate attitudes of commitment, parience, continuity, trust, and confidence with established cooperation and common interests. Overall, most successful PPPs experience community and lender support. ${ }^{56}$ A truly successful PPP may even evolve into a new, single organization which may eventually partner with others, thus restarting the partnering cycle, such as the $501 \mathrm{c}(3)$ organization described earlier. While these elements do not give a step-by-step recipe for success, they do touch on valuable elements that are essential to any type of group project, PPPwise.

\section{Creating Successful PPPs in Charles County}

There are many elements that can assist Charles County in improving its overall situation that when implemented will also encourage the success of PPPs. The county must find ways to encourage community participation in its zoning approval process and it must implement better processes for planning and approving major developmenrs, which must include stakeholders within the community. It should also increase the percentage of the county budget allocated to economic development from the .5 percent in fiscal year 1999 to at least .7 percent in fiscal 2001 to help the EDC address issues that have lacked funding. More funds should also be allocated to the capital improvement budger to establish a reserve for use in partnering arrangements in order to increase the number of ready-to-build sires throughour the county.

Building trust between the public and private sectors is criti- 
cal to the use of PPPs and future development efforts. It may not be easy to achieve because the two sectors are assumed not to share the same goals. Private firms respond to closed groups of people, such as stockholders, while public agencies have to respond to the public-atlarge with more varied interests than the private sector. ${ }^{57}$ However, to be successful, a PPP must recognize these perceived differences and use them to its advantage by allowing partners to benefit in the specific areas which are of most value to them and to those to which they respond. In addition, differences can be utilized to the advantage of the PPP when involving the community in decisions by adding skills and viewpoints that increase the quality and completeness of decisions. Bringing all parties together with differing interests and specific areas of expertise, while time consuming, will create an outcome that is more beneficial for all involved. The partnership agreement should discuss these items in detail.

Charles County must also be more proactive towards development and its economic development future. The county should complete a commercial/industrial inventory as proposed in its Comprehensive Plan in order to allocate resources more efficiently and determine the preferred type of developers in order to identify the best sites and specific incentives/benefits to attract them. The county should use PPPs not only to develop Bryan's Road, but to also increase the number of ready-to-build commercial/industrial sites throughout the county to meet market demand and provide flexibility and reduced site selection costs to potential commercial/industrial developers.

\section{Conclusion}

Industrial/commercial economic development has been limited in Charles County. The shortage of improved readyto-build industrial/commercial sites is one possible reason why this development has not occurred. This lack of economic development has impeded the county's efforts to provide well-paying jobs and necessary services to residents because of the resulting imbalance between residential and industrial/commercial tax revenues versus outlays. Use of the PPP strategy outlined in this analysis can act as a catalyst to encourage economic development that begins to address this imbalance.

The PPP outlined in this analysis would benefit Charles County by increasing the number of improved, ready-tooccupy commercial/industrial sites available in the county. In addition to establishing a PPP to increase the number of sites on which private developers can build, the county can use the PPP concept to encourage community involvement in economic development issues. The use of a countywide PPP organization similar to that used in the Baltimore Inner Harbor example can assist in facilitating this new approach.

Charles County has many strengths, such as its zoning of development and non-development areas and use of a comprehensive plan. However, community involvement is not common. Even though there was a community group that helped create the county's Comprehensive Plan, zoning decisions are made without obtaining input from the residents of the different election districts. Unless the county can attempt to speak with one voice by including stakeholders in important decisions, conflicts will continue and development plans will lack legitimacy with residents. The experience of the county with the Chapman's Landing development may be repeated again and again.

The establishment and use of PPPs as discussed in this analysis is a starting point toward the building of better communication and trust within any community and in turn toward fostering better economic development decisions. Success depends on individuals in the community and the government being willing to work together and to commit to these new roles and relationships. Increased commercial/ industrial development, resulting from various strategies including PPPs, can assist in balancing Charles County's tax base and help finance the public facilities and services required by the increasing population. PPPs can help establish a common agenda between private investors who own land, communities that use the land, and public officials who regulate its use in order to improve the economic development condition of any community. The recommendations included in this analysis, while specific to Charles County, provide valuable lessons that can be used by other municipalities experiencing similar economic challenges or by those looking for an innovative way to involve the community in development decisions.

\section{Notes}

${ }^{1}$ Charles County Government, Comprehensive Plan (1997).

${ }^{2}$ Tay Geuisman, Economic Planning Commission, multiple interviews.

${ }^{3}$ Charles County Government, Comprehensive Plan (1997).

Teter Eisinger, The Rise of the Entrepreneurial State: State and Local Economic Development Policy in the U.S. (Madison, Wisconsin: University of Wisconsin Press, 1988). 
"Norman Walzer and Brian D. Jacobs, Public-Priwate Partnerships for Local Economic Development (Connecticut: Praeger Publishers, 1998).

"Shaffer, Ron, Community Economics, Economic Structure and Change in Smaller Communities (Iowa: Iowa University Press 1989), 225.

'Institure for Cultural Landscape Studies. Practitioners' Roundtable, "The Paradoxes of Partnership" <http://www.ids.harvard.edus.

"Alice Ingerson. "Is Public-Private Partnership Empty Rhetoric?" $<$ www.icls.harvard.edus.

'Clarke Susan E. and Gary L. Gaile, The Work of Cities (Minnesora: University of Minnesota Press, 1998).

${ }^{10}$ Walzer and Jacobs.

"Clarke and Gaile.

${ }^{12}$ Ibid.

${ }^{13}$ Ibid.

14 Ibid.

is Walzer and Jacobs.

${ }^{16}$ Montgomery County Department of Park and Planning, Public/Private Partnerships and Business Improvement Districts, 1997.

${ }^{17}$ Institute for Culcural Landscape Studies, "Are Parrnerships Undemocratic?" <http://www.icls.harvard.edu>.

${ }^{18}$ Ibid.

"Katharine C. Lyall, Public-Private Partnerships in the Carter Years. Public-Private Partnerships Improving Urban Life (New York: The Academy of Political Science, 1986).

${ }^{20}$ Baltimore City Department of Planning, The Baltimore Harbor Book (1984).

${ }^{21}$ Ibid.

22 Ibid.

"Ibid.

${ }^{24} \mathrm{lbid}$.

25 Ibid.

26. Ibid.

${ }^{2}$ Charles County Government, Comprehensive Plan (1997).

Ibid.

"Lipman, Frizzel, and Mirchell, Property Tax Base Study, Charles County Maryland (1999).

${ }^{39}$ Charles County Government, Bond Rating Report (McGuire, Woods,
Battle \& Boothe LLP. Bond Counsel. 1999).

"Charles County Government, Fisctl Year 1999: Adopted Budget, Vol. I (30 June 1999).

${ }^{32}$ Charles County (1997).

slbid.

${ }^{34}$ Charles County Government. Fiscal Year 1999: Adopted Budget, Vol I (30 June 1999).

"Charles County (1997).

Ibid.

${ }^{37}$ Bill Vaughan, personal communication. See: Bill Vaughan, Demographics, Prince William County Economic Development Office, May 16, 1999.

${ }^{18}$ Charles County Government (1997).

${ }^{37}$ United Stares Bureau of the Census <http://www.census.gov>.

*Shaffer, 225

${ }^{41}$ Geuisman.

${ }^{4 z}$ Charles Ellison, Vice President, Legend Properties, Inc, interview (22 February 1999.)

${ }^{43}$ Ibid.

${ }^{44}$ Sierra Club, Maryland Chapter <http://www.sierradub.org>.

${ }^{44}$ Magoon, Steve, Director, Charles County Department of Planning and Growth Management, interview.

4i. Joe Mangini. Associate Director, Economic Development Commission, interview (15 March 2000).

4. Geuisman.

${ }^{48}$ Charles County Government (1997).

44 Charles County Government, Traffic Assessment Zone data (1993).

${ }^{*}$ Chuck Ellison, Charles County Quote, 2 (1998).

"Montgomery County Department of Park and Planning.

52 Myers, Phyllis, "Direct Funding of Nomprofit Land Protection: A New Genre of State Land Conservation Programs. Land Conservation"Through Public/Private l'artnerships," (1993), 223-235.

${ }^{3}$ Ibid.

i4 Urban Studies Council. Urban Affairs Conference (Fifth Annual). Public-Private Partnerships in Urban Development. (Chapel Hill, North Carolina, 1983).

"Institure for Culural Landscape Studies. "Factors in Successful PublicPrivate Partnerships" <htrp://www.icls.harvard.cdu>. 
5i, Walzer and Jacobs.

"Ibid.

\section{Bibliography}

Baltimore City Department of Planning. The Baltimore Harbor Book, (1984).

Charles County Government. Bond Rating Report. McGuire, Woods, Batrle \& Boothe LL.P, Bond Counsel (1999).

Charles County Government. Comprehensive Plan (1997).

Charles County Government. Fiscal Year 1999: Adopted Budget. vol. I (July 1, 1998-June 30). (1999)

Charles County Government. Traffic Assessment Zone Data (1993).

Clarke, Susan E. and Michael J. Rich. "Making Money Work: The New Urban Policy Arena." Research in Urban Policy 1 (1985): $25-38$.

Clarke Susan E. and Gary L.Gaile. The Work of Cities, Minnesota: University of Minnesora Press (1998).

Edwards, Aubrey. Director, Economic Planning Commission, Interview (22 March 1999).

Eisinger, Peter K. The Rise of the Entrepreneurial State: State and Local Economic Development Policy in the U.S. Madison, Wisconsin: Universicy of Wisconsin Press, (1988).

Ellison, Charles. 1998, Charles County Quote. 2.

Ellison, Charles. Vice President, Legend Properties, Inc. Interview. (22 February 1999).

Friends of Mount Aventine, Bryan's Road, Maryland. (April 3, 1999) $<$ http://www.radix.net/ forma>.

Geuisman, Tay. Economic Planning Commission. Multiple interviews.

Grant, Mary L., Charles Councy Department of Planning and Growth Management, Interview (9 April 1999).

Ingerson, Alice. "Is Public-Private Partnership Empty Rhetoric?" (24 February 2000). <http://www.icls.harvard.edu>.

Institure for Cultural Landscape Studies. "Are Partnerships Undemocratic?" (24 February 2000) <htrp://www.icls.harvard.edus.

Institure for Cultural Landscape Studies. Practitioners' Roundtable, "The Paradoxes of Partnership." (24 February 2000) <htcp:// www.icls.harvard.edus.

Lipman, Frizzel, and Mitchell. Property Tax Base Study, Charles County Maryland (1999).

Lyall, Katharine, C. Public-Private Partnerships in the Carter Years: Public-Private Partnerships Improvine Urban Life. New York: The
Academy of Political Science, 1986.

Mangini, Joe. Associate Direcror, Economic Development Commission. Interview (15 March 2000).

Magoon, Steve. Director, Charles County Department of Planning and Growth Management. Multiple interviews.

Montgomery County Department of Park and Planning. "Public/Private Partnerships and Business Improvement Districts" (1997).

Myers, Phyllis. "Direct Funding of Nonprofit Land Protection: A New Genre of State Land Conservation Programs. Land Conservation Through Public/Private Partnerships" (1993).

Shaffer, Ron. Community Economics, Economic Structure and Change in Smaller Communities. Ames, Iowa: Iowa State University Press, 1989.

Sierra Club, Maryland Chapter <http:/www.sierraclub.org>.

United States Bureau of the Census <htcp://www.census.gov>.

Urban Studies Council. Urban Affairs Conference (Fifth Annual). PublicPrivate Partnerships in Urban Development. Chapel Hill, North Carolina, 1983.

Vaughan, Bill. Demographics, Prince William County Economic Development Office (16 May 1999).

Walzer, Norman and Brian D. Jacobs Public-Private Partnerships for Local Economic Development. Connecticut: Praeger Publishers, 1998.

Winkler, Richard A. Financial Branch, Charles County Treasurer's Office. Interview 17 May 1999.

Winter, Alex Winter. Friends of Mt. Aventine. Interview (26 April 1999). 